\title{
THE EFFECTIVENESS OF PROTECTIVE POWER OF STARFRUIT (Averrhoa bilimbi) JUICE IN CATFISH AGAINST MOTILE AEROMONAS SEPTICEMIA DISEASES
}

\author{
Sefti Heza Dwinanti ${ }^{* 1}$, Ratu Brata T. Mengkrin ${ }^{1}$, Ade Dwi Sasanti $^{1}$ \\ ${ }^{1}$ Aquaculture Study Program, Faculty of Agriculture, Sriwijaya University, \\ Palembang-Prabumulih St. KM 32, Ogan Ilir, Sumatera Selatan, Indonesia \\ *Correspondence : \\ sefti.heza@unsri.ac.id \\ Received : 2021-05-21 \\ Accepted : 2021-06-23 \\ Keywords : \\ Catfish, Immunostimulant, \\ Motile Aeromonas Septicemia, \\ Starfruit

\begin{abstract}
Starfruit contains active ingredients such as flavonoids, phenols, antioxidants and vitamin $\mathrm{C}$ so that it can be used as an immunostimulant in catfish farming activities. Motile Aeromonas Septicemia (MAS) is one of the obstacles that can cause catfish farming losses. This study aims to determine the effect of differences in timing of feeding containing starfruit juice to protect catfish from MAS disease. The study was designed using a completely randomized design (CRD) consisting of 6 treatments $(P)$ in the form of feeding duration containing starfruit for 7 days (P1), 14 days (P2), 21 days (P3), 28 days (P4). and 35 days (P5) and control of feeding without star fruit juice (PO). The research was carried out at the Aquaculture Laboratory, Sriwijya University. The dose of star fruit juice mixed in the feed is $300 \mathrm{~mL} . \mathrm{Kg}-1$ while the catfish used is $8-12 \mathrm{~cm}$ in size. The challenge test used Aeromonas hydrophilla bacteria with a density of 108 CFU.mL-1 which was injected as much as $0.5 \mathrm{~mL}$.tail-1 intramuscularly. The results showed that administration containing starfruit juice for 28 days provided the best protection. Based on the hematological test the day before and before infection, the delta decreased the hematocrit by $3 \%$ and the delta decreased the erythrocyte count by 3,103 cells.mL-1. In addition, live feed after infection was $100 \%$, prevalence was $17.78 \%$ and there was no effect of giving starfruit juice on growth and feed efficiency.
\end{abstract}

\section{INTRODUCTION}

Motile Aeromonas Septicemia (MAS) or hemorrhagic septicemia is a common bacterial disease that attacks freshwater fish culture (Rasmussen-Ivey et al., 2016). Death and organ damage caused by infection with Aeromonas hydrophila bacteria, the causative agent of MAS disease, can cause significant economic losses for fish farmers (Austin \& Austin, 2016; Zhang et al., 2016). Therefore, prevention efforts are necessary so that farmers avoid losses.

The application of immunostimulants in cultivation activities is an alternative to avoid disease occurrence (Citarasu, 2010) (Reverter et al., 2017). Belimbing wuluh (Averrhoa bilimbi) is a medicinal plant that can be used to treat disease and also prevent disease (Chaitanya kumari \& Chaitanya, 2017; Yan et al., 2013). Starfruit juice added to catfish feed at a dose of 
Journal of Fish Health Vol. 1 (1) - Juni 2021

Dwinanti et al. (2021)

https://doi.org/10.29303/jfh.v1i1.152

300 mg.Kg-1 can be used as a drug to cure MAS (Agustina et al., 2017). The content of starfruit which contains alkaloid compounds is able to damage bacterial cell walls so that bacterial growth is inhibited or can cause death (Cushnie et al., 2014). In addition to alkaloids, starfruit also contains flavonoid compounds and vitamin $\mathrm{C}$ which can improve the immune system (Roy \& Rv, 2011).

The use of medicinal plants for a long time has the potential to have adverse side effects on the body's metabolism, in addition to ineffective addition of raw materials will cause production costs and affect the profits of cultivators (Fatima \& Nayeem, 2016). The performance or efficacy of medicinal plants to stimulate the non-specific immune system in fish is highly dependent on the dose and duration of exposure or the duration of consumption and the amount given. Therefore, this study aimed to determine the period of feeding containing starfruit juice against the protective power of catfish against MAS disease. This research is expected to be a reference for the application of the use of starfruit in catfish feed during the production cycle so that farmers are protected from Aeromonas hydrophila bacteria attack.

\section{METHODOLOGY}

This study used a completely randomized design with 6 treatments and three replications. The treatment given was a long period of time for feeding containing star fruit juice as much as $300 \mathrm{~mL} . \mathrm{kg}-1$. The treatment given is illustrated in Figure 1 as follows:

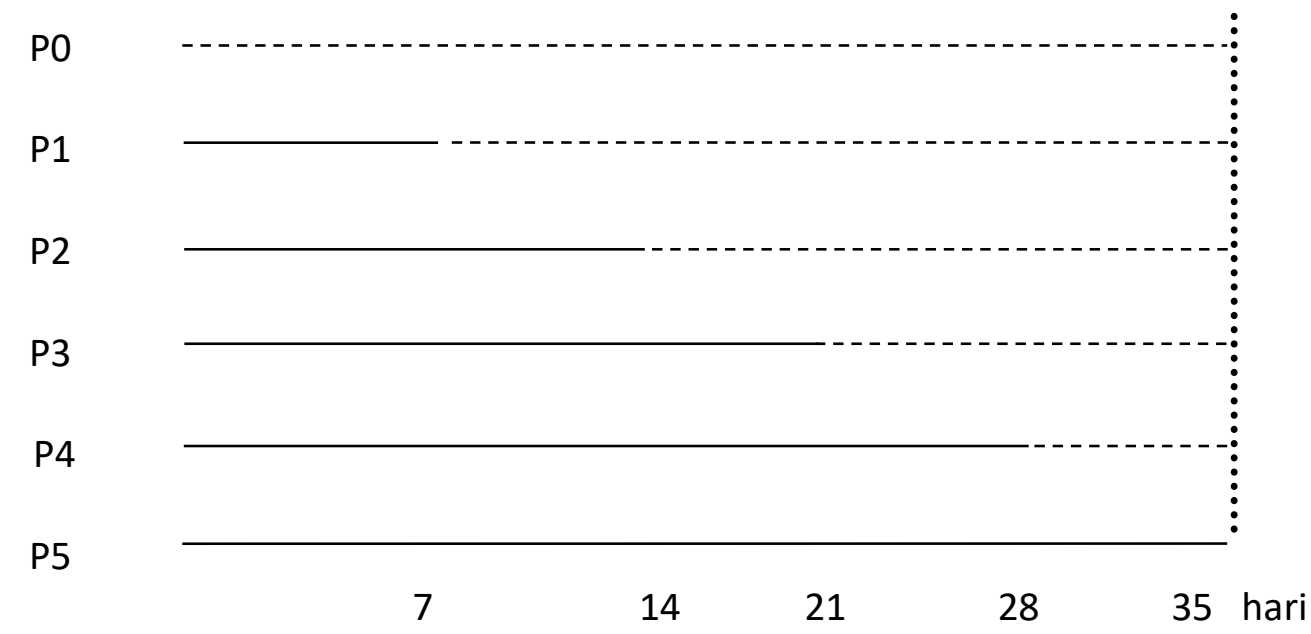

Note:

P0 : Feeding without star fruit juice (control);

P1 : Feeding with the addition of star fruit juice for 7 days;

P2 : Feeding with the addition of star fruit juice for 14 days;

P3 : Feeding with the addition of star fruit juice for 21 days;

P4 : Feeding with the addition of star fruit juice for 28 days;

P5 : Feeding with the addition of starfruit juice for 35 days;

.... : : Infection with Aeromonas hydrophila

:-- : Feedling without starfruit

: Feeding with starfruit

Figure 1. Research design illustration

The materials used are catfish measuring $10-12 \mathrm{~cm}$, star fruit wuluh that is ripe with a yellowish green color and soft, commercial feed and Aeromonas hydrophila bacteria. While the maintenance container used is an aquarium measuring $30 \times 30 \times 30 \mathrm{~cm} 3$. The stocking 
Journal of Fish Health Vol. 1 (1) - Juni 2021

Dwinanti et al. (2021)

https://doi.org/10.29303/jfh.v1i1.152

density of fish was 1 fish.L-1, while the density of bacteria used to infect fish was 108 CFU.mL1.

The treatment feed used commercial feed which was re-pelleted by adding $300 \mathrm{~mL}$ wuluh starfruit juice, while the control feed used distilled water with the same concentration (Agustina et al., 2017). Giving the amount of feed as much as 3\% of fish biomass in the morning, afternoon and evening. Fish infection was carried out simultaneously on the 36th day by intramuscular as much as $0.1 \mathrm{ml} /$ head. Parameters observed were hematocrit levels, erythrocyte count, disease prevalence, fish survival, feed efficiency, and growth. Water quality during maintenance is monitored to be at the conditions recommended by the Indonesian National Standard (SNI 6484.4:2014).

Data on prevalence, survival, growth obtained are presented in tabular form and analyzed statistically using analysis of variance with $95 \%$ confidence level. If the results of the diversity show that the treatment has a significant effect, then it is continued with the further test of BNT (Small Significant Difference). While water quality data (temperature, $\mathrm{pH}$, dissolved oxygen and ammonia), hematocrit value, erythrocyte and feed efficiency were processed descriptively.

\section{RESULT}

The results of the measurement of total erythrocytes and hematocrit during maintenance are presented in Table 1 below.

Table 1. Total erythrocytes and hematocrit of catfish during rearing

\begin{tabular}{ccccccc}
\hline \multirow{2}{*}{ Treatment } & \multicolumn{3}{c}{ Total erythrocytes $\left(\mathrm{sel} / \mathrm{mm}^{3}\right)$} & \multicolumn{3}{c}{ Results of Hematocrit Levels (\%) } \\
\cline { 2 - 7 } & $\begin{array}{c}\text { Before } \\
\text { infection }\end{array}$ & $\begin{array}{c}\text { post } \\
\text { infection }\end{array}$ & $\Delta$ erythrocytes & $\begin{array}{c}\text { Before } \\
\text { infection }\end{array}$ & $\begin{array}{c}\text { post } \\
\text { infection }\end{array}$ & $\Delta$ Hematocrit \\
\hline P0 & 2,7 & 2,1 & $-0,6$ & 27 & 20 & -7 \\
P1 & 2,6 & 2,1 & $-0,5$ & 27 & 21 & -6 \\
P2 & 2,7 & 2,2 & $-0,5$ & 28 & 22 & -6 \\
P3 & 2,8 & 2,3 & $-0,5$ & 29 & 23 & -6 \\
P4 & 2,7 & 2,4 & $-0,3$ & 29 & 25 & -4 \\
P5 & 2,7 & 2,3 & $-0,4$ & 29 & 25 & -4 \\
\hline
\end{tabular}

Note: the sign (-) indicates a downward trend

The prevalence and survival values of fish observed after two days post-infection are presented in Table 2 while the values for monitoring water quality during rearing are presented in Table 3.

Table 2. Prevalence and survival values of fish after infection

\begin{tabular}{ccc}
\hline Treatment & $\begin{array}{c}\text { Catfish prevalence (\%) } \\
\mathrm{BNT}_{0,05}=11,50\end{array}$ & $\begin{array}{c}\text { Survival rate }(\%) \\
\mathrm{BNT}_{0,05}=10,06\end{array}$ \\
\hline P0 & $100,00^{\mathrm{d}} \pm 0,00$ & $0^{\mathrm{a}} \pm 0,00$ \\
P1 & $100,00^{\mathrm{d}} \pm 0,00$ & $0^{\mathrm{a}} \pm 0,00$ \\
P2 & $66,67^{\mathrm{c}} \pm 6,67$ & $75,56^{\mathrm{b}} \pm 1,3$ \\
P3 & $42,22^{\mathrm{b}} \pm 3,85$ & $84,44^{\mathrm{b}} \pm 3,85$ \\
P4 & $17,78^{\mathrm{a}} \pm 3,85$ & $100^{\mathrm{c}} \pm 0,00$ \\
P5 & $17,78^{\mathrm{a}} \pm 3,85$ & $100^{\mathrm{c}} \pm 0,00$ \\
\hline
\end{tabular}


Journal of Fish Health Vol. 1 (1) - Juni 2021

Dwinanti et al. (2021)

https://doi.org/10.29303/jfh.v1i1.152

Table 3. Water quality during maintenance

\begin{tabular}{crccc}
\hline Treatment & Temperature $\left({ }^{\circ} \mathrm{C}\right)$ & $\mathrm{pH}$ & $\begin{array}{c}\text { Dissolved oxygen } \\
\left(\mathrm{mg} . \mathrm{L}^{-1}\right)\end{array}$ & $\begin{array}{c}\text { Ammonia }\left(\mathrm{mg} . \mathrm{L}^{-}\right. \\
{ }^{-}\end{array}$ \\
\hline P0 & $27-28,7$ & $5,3-7,2$ & $5,20-6,20$ & $0,13-0,19$ \\
P1 & $27-28,2$ & $5,3-7,2$ & $5,20-6,20$ & $0,13-0,19$ \\
P2 & $27-28,3$ & $5,6-7,5$ & $5,30-6,30$ & $0,07-0,09$ \\
P3 & $27-28,9$ & $5,3-7,7$ & $5,40-6,01$ & $0,09-0,11$ \\
P4 & $27-28,2$ & $5,2-7,7$ & $4,80-5,97$ & $0,12-0,14$ \\
P5 & $27-28,4$ & $5,2-7,3$ & $5,47-6,11$ & $0,10-0,14$ \\
$\begin{array}{c}\text { Reference } \\
\text { (Standar Nasional } \\
\text { Indonesia, 2014) }\end{array}$ & $25-30$ & $6,5-8$ & Min 3 & Max 0,1 \\
\hline
\end{tabular}

\section{DISCUSSION}

The blood picture profile is one indicator of fish health status whether the fish is in good health or not (Lusiastuti \& Hardi, 2011). Pathogenic infections and the food consumed and the activities of fish can affect the profile of the blood picture either as a short-term response such as stress or a long-term response such as a fish infected with an acute or chronic disease. Aeromonas hydrophila bacteria have virulence in the form of hemolysin enzymes that are able to break down erythrocytes so that when fish are infected it will affect the number of erythrocytes and hematocrit (El-gohary et al., 2020; Rasmussen-Ivey et al., 2016). Based on Table 1, it can be seen that the number of erythrocytes and hematocrit levels decreased in all treatments. The highest decrease in the number of erythrocytes was found in the group of fish fed with pellets without the addition of starfruit, while the lowest decrease in erythrocytes was found in the group of fish fed for 28 days with pellets containing starfruit. The same thing is also reflected in the hematocrit level, where giving pellets containing starfruit juice for more than 28 days has the lowest decrease in hematocrit levels. The number of erythrocytes is directly proportional to the hematocrit value, because the number of lysed erythrocytes will cause a low hematocrit value. A low hematocrit value indicates that the fish is anemic and illustrates the occurrence of disease infection or stress. The hematocrit value in each fish species is strongly influenced by feed, size and water temperature (Seibel et al., 2021). Feeding containing starfruit juice showed a pattern that the longer it was given, the higher the hematocrit value and the smaller the decrease in the hematocrit value when the fish were infected with A. hydrophila. Belimbing wuluh has flavonoid compounds that can stimulate the production of immune cells including red blood cells when given in the right amount (Roy \& Rv, 2011; Suluvoy \& Berlin Grace, 2017; Yan et al., 2013).

Disease prevalence and catfish survival after infection were observed for 2 days. The fish infected with A. hydrophila bacteria that experienced acute death showed a bloated belly and reddish yellow color at the urogenital tip and the dorsal part, precisely at the injection site. While the fish that survived showed clinical symptoms other than wounds at the injection site, each end of the fin was bleeding. A. hydrophila that attacks catfish can cause death up to $100 \%$ with clinical symptoms that include mucus production, abscesses, hemorrhage, exophthalmia, decreased appetite, and passive movement (Zhang et al., 2016) (Cipriano \& Austin, 2011). ). Based on Table 2, the prevalence value of giving pellets containing starfruit for 28 days was not significantly different from 35 days and was the lowest prevalence value. 
Journal of Fish Health Vol. 1 (1) - Juni 2021

Dwinanti et al. (2021)

https://doi.org/10.29303/jfh.v1i1.152

This shows that giving starfruit juice for more than 28 days provides a better protection value than the other treatments. Feeding treatment for 7 days was not significantly different from the control treatment, this shows that the short feeding time ( $<7$ days) was not able to protect fish from MAS disease. Fish mortality in this study reached $100 \%$ and the lowest was $17.78 \%$, namely in the group that was given treatment feed for more than 28 days.

Water quality during maintenance is still in the optimal range according to the reference of the national standardization body. At the value of ammonia, maintenance water is outside the optimal value. However, during the rearing period (before infection) there were no fish deaths. This shows that catfish can still tolerate levels of dissolved ammonia in the water.

\section{CONCLUSION}

The use of wuluh starfruit juice in feed as an effort to prevent motile aeromonas septicemia (MAS) disease in catfish provides different protection depending on the length of time given. Feeding containing starfruit juice for 28 days gave the highest protection value and was not significantly different if the feeding period was added to 35 days. The lowest prevalence value was obtained in the treatment of long feeding containing starfruit juice for 28 and 35 days, namely $17.78 \%$ and $100 \%$ survival.

\section{ACKNOWLEDGMENT}

Thank you to Research and Community Service Institute of Sriwijaya University for fully funding this research with contract number 0146,101/UN9/SB3.LP2M.PT/2019.

\section{REFERENCES}

Agustina, H., Sasanti, A. D., \& Wijayanti, M. (2017). Penambahan Sari Buah Belimbing Wuluh (Averrhoa bilimbi) Pada Pakan untuk Mengobati Ikan lele (Clarias sp) yang di Infeksi Aeromonas hydrophila. Jurnal Akuakultur Rawa Indonesia, 5(2), 155-168.

Austin, B., \& Austin, D. A. (2016). Bacterial fish pathogens: Disease of farmed and wild fish. In Bacterial Fish Pathogens: Disease of Farmed and Wild Fish (6th ed.). Springer International Publishing.

Chaitanya kumari, S., \& Chaitanya, S. (2017). Studies on Bilimbi. International Journal of All Research Education and Scientific Methods (IJARESM), 5(7), 2455-6211.

Cipriano, R. C., \& Austin, B. (2011). Furunculosis and other aeromonad diseases. In P. T. K. Woo (Ed.), Fish Diseases and Disorders (second, Vol. 3, pp. 424-483). CAB International. https://doi.org/10.1079/9781845935542.0424

Citarasu, T. (2010). Herbal biomedicines: A new opportunity for aquaculture industry. Aquaculture International, 18(3), 403-414. https://doi.org/10.1007/s10499-009-9253-7

Cushnie, T. P. T., Cushnie, B., \& Lamb, A. J. (2014). Alkaloids: An overview of their antibacterial, antibiotic-enhancing and antivirulence activities. International Journal of Antimicrobial Agents, 44(5), 377-386. https://doi.org/10.1016/j.ijantimicag.2014.06.001

El-gohary, F. A., Zahran, E., Abd El-Gawad, E. A., El-gohary, A. H., Abdelhamid, F. M., El-mleeh, A., Elmahallawy, E. K., \& Elsayed, M. M. (2020). Investigation of the prevalence, virulence genes, and antibiogram of motile aeromonads isolated from nile tilapia fish farms in egypt and assessment of their water quality. Animals, 10(8), 1-19. https://doi.org/10.3390/ani10081432 
Journal of Fish Health Vol. 1 (1) - Juni 2021

Dwinanti et al. (2021)

https://doi.org/10.29303/jfh.v1i1.152

Fatima, N., \& Nayeem, N. (2016). Toxic Effects as a Result of Herbal Medicine Intake. In M. L. Larramendy \& S. Soloneski (Eds.), Toxicology - New Aspects to This Scientific Conundrum (pp. 193-207). InTech. https://doi.org/10.5772/64468

Lusiastuti, A. M., \& Hardi, E. H. (2011). Gambaran darah sebagai indikator kesehatan pada ikan air tawar. Prosiding Seminar Nasional Ikan VI "Peranan Iktiologi Dalam Mengantisipasi Dan Meminimalkan Kepunahan Keanekaragaman Jenis Ikan Akibat Perubahan Iklim Global Dan Faktor Destruktif," 6(1), 65-69.

Rasmussen-Ivey, C. R., Figueras, M. J., McGarey, D., \& Liles, M. R. (2016). Virulence factors of Aeromonas hydrophila: In the wake of reclassification. Frontiers in Microbiology, 7(AUG), 1-10.

Reverter, M., Tapissier-Bontemps, N., Sasal, P., \& Saulnier, D. (2017). Use of Medicinal Plants in Aquaculture. In Diagnosis and Control of Diseases of Fish and Shellfish (pp. 223-262).

Roy, A., \& Rv, G. (2011). Averrhoa bilimbi Linn-Nature's Drug Store-A Pharmacological Review Plants provide wealth of. Int. J. Drug Dev. \& Res, 3(3), 101-106.

Seibel, H., Baßmann, B., \& Rebl, A. (2021). Blood Will Tell: What Hematological Analyses Can Reveal About Fish Welfare. Frontiers in Veterinary Science, 8(March), 1-21. https://doi.org/10.3389/fvets.2021.616955

Standar Nasional Indonesia. (2014). Ikan lele dumbo (Clarias sp): Bagian 4. Produksi benih.

Suluvoy, J. K., \& Berlin Grace, V. M. (2017). Phytochemical profile and free radical nitric oxide (NO) scavenging activity of Averrhoa bilimbi L. fruit extract. 3 Biotech, 7(1). https://doi.org/10.1007/s13205-017-0678-9

Yan, S. W., Ramasamy, R., Alitheen, N. B. M., \& Rahmat, A. (2013). A comparative assessment of nutritional composition, total phenolic, total flavonoid, antioxidant capacity, and antioxidant vitamins of two types of malaysian underutilized fruits (averrhoa bilimbi and averrhoa carambola). International Journal of Food Properties, 16(6), 1231-1244.

Zhang, D., Xu, D. H., \& Shoemaker, C. (2016). Experimental induction of motile Aeromonas septicemia in channel catfish (Ictalurus punctatus) by waterborne challenge with virulent Aeromonas hydrophila. Aquaculture Reports, 3, 18-23. https://doi.org/10.1016/j.aqrep.2015.11.003 